DENNETT, Daniel. C. Breaking the spell: religion as a natural phenomenon. Penguin, 2006. 476pp. Trad. port.: Quebrar o feitiço: a religião como fenómeno natural. Lisboa: Esfera do Caos, 2008. 336pp.

\title{
BREAKING THE SPELL: É A RELIGIÃO UM FENÔMENO NATURAL?
}

\section{Everaldo Cescon}

O novo livro de Daniel Dennett inscreve-se na corrente do naturalismo filosófico e tenta responder à segunda pergunta que David Hume pôs na sua obra História natural da religião: quais as fontes humanas da religião? No intenso debate sobre o New Atheism, que a partir de 2007 dominou os ambientes intelectuais, este livro foi aproximado a Letter to a Christian Nation (2006) de Sam Harris e a The God Delusion (2006) de Richard Dawkins.

Se Al Qaeda tivesse destruído a Estátua da Liberdade ao invés do World Trade Center, como os americanos teriam reagido? Dennett se declara propenso a considerar que neste caso a fúria com a qual muitos americanos teriam reagido ao ataque do símbolo nacional mais amado teria tornado difícil dar uma resposta lúcida ao terrorismo. Isto porque os símbolos escondem em si um grande perigo: "podem se tornar sagrados demais". Se isto vale para todos os símbolos, vale ainda mais para aqueles religiosos. Segundo Dennett, uma das tarefas mais importantes dos chefes religiosos de todos os credos deveria ser a de difundir e consolidar a convicção de que é extremamente desonroso agredir os fiéis de outra religião nos seus símbolos. Algo, entretanto, que ele também negligencia ridicularizando os católicos que, na comunhão, crêem tomar o corpo e o sangue de Cristo, convidando-os a submeter o pão e o vinho a análise para encontrar o DNA de Jesus.

$\mathrm{Na}$ primeira parte, composta por três capítulos e intitulada "Abrir a Caixa de Pandora", Dennett procura persuadir o leitor a aceitar este tipo de estudo da religião.

A mais interessante é a segunda parte, intitulada "A Evolução da Religião" e composta por quatro capítulos. Nela, o autor apresenta a sua tentativa de explicação biológica da religião, mas não apresenta qualquer idéia central; apenas descreve hipóteses estimulantes e apresenta com eloqüência e entusiasmo o estado atual da investigação na área.

O autor levanta questionamentos acerca da religião. Como ela surgiu? Por que razão as religiões têm certas características distintivas - respeito pelo sagrado, 
rituais, iniciações, ortodoxia - e procuram se proteger da análise científica religiosamente neutra? Sobre estes aspectos, Dennett apresenta algumas idéias iluminadoras. Por exemplo, se duas religiões estiverem em competição, a religião que obrigar a rituais incômodos e à repetição de doutrinas incompreensíveis tem tendência a cativar mais fiéis. Isto acontece porque um dos aspectos centrais da mentalidade religiosa é o uso intenso de dispositivos que visam proteger a própria crença.

A terceira, e última, parte do livro dirige-se ao grande público, como a primeira, e aborda os problemas políticos e sociais que as religiões atualmente levantam. Devemos aceitar que as crianças sejam educadas religiosamente pelos seus pais? Será isso aceitável, ou uma forma de violar o direito das crianças à informação não tendenciosa? Quando há vastos setores religiosos radicais e bombistas o que devem fazer os religiosos moderados? Ficar em silêncio, ou tomar uma posição firme contra tais desvios da sua religião?

Breaking the spell pode ser considerado o manifesto dos brights, uma espécie de fraternidade neo-iluminista, constituída por ateus militantes, materialistas, livres pensadores, agnósticos e céticos, que se propõe a orientar a opinião pública em relação a uma abordagem naturalista da religião e de fazer os votos convergirem para personalidades políticas que adotam um ponto de vista "secular". Muitos deles estão convencidos de que o mundo seria um lugar melhor se as religiões não existissem. Isto porque as religiões, como a história demonstraria, são portadoras de guerras, terrorismo e mortes. Dennett, entretanto, não se dá conta de que as maiores tragédias do século XX, a shoah e o gulag, foram o êxito de ideologias como o nazismo e o comunismo, que se propunham a aplicar um projeto inspirado no darwinismo e no materialismo científico, respectivamente. A falência das tentativas de abolir a religião postas em ato na União Soviética e na China maoísta parecem ter demonstrado que também neste campo o proibicionismo não vale a pena.

Para Dennett, as religiões tornaram-se muito perigosas, seja para a estabilidade dos países, seja pelos entraves que põem às relações internacionais, enquanto terreno de cultivo de fundamentalismos. $O$ pensamento de Dennett se dirige, naturalmente, à situação religiosa dos Estados Unidos, ao medo suscitado pelos atentados de 11 de setembro de 2001, à preocupação com a proliferação do mercado de credos religiosos. A idéia de que há crenças que nos fazem viver e mitos que jamais devem ser demolidos, como aqueles das religiões, confrontase cada vez mais, segundo ele, não só com aquela da exigência da verdade científica, mas também com as exigências de relações pacíficas, justas e livres. As idéias, as crenças e os fenômenos culturais, exatamente como os demais produtos da natureza, podem ser muito úteis, mas também podem adoecer e degenerar. Neste caso, devem ser curados ou eliminados. Dennett defende que o campo da saúde pública, inclusive a saúde cultural, será o grande desafio 
deste século. Para decidir aquilo que é culturalmente são ou insano, como a religião, Dennett sugere recorrer a um júri de cientistas.

Dennett declara não querer entrar no mérito das discussões acerca da existência de Deus (na realidade o fará diversas vezes), porque, mesmo se existisse, Deus seria um objeto incognoscível e, portanto, o problema da sua existência não tem qualquer interesse. Chegou a hora, segundo ele, de quebrar o feitiço que considera a religião fruto de uma revelação sobrenatural. É preciso gritar que o rei está nu, isto é, que as crenças e as práticas religiosas são fenômenos totalmente naturais.

Breaking the spell se situa no programa de naturalização da filosofia e das ciências sociais cujos êxitos são discutíveis. O "natural" é descrito aqui simplesmente como o oposto ao "sobrenatural"; natural não é somente o mundo exterior, mas também aquele interior enquanto pode ser tornado objeto de estudo científico. Em Dennett esta concepção é sustentada por uma epistemologia ultrapassada que estabelece uma distinção entre as crenças da ciência (campo do verificável) e as da religião (campo do não verificável). Não parece considerar que o nosso modo de conhecer está intrinsecamente ligado ao nosso modo de estar no mundo: antes mesmo de conhecer, desenvolvemos uma atitude natural de acreditar na existência dos corpos materiais, das outras mentes e da uniformidade da natureza. Crer não é, como propõe Dennett, um excesso do processo de conhecer, mas a sua origem. Infelizmente, estes temas cruciais para qualquer teoria naturalista não encontram em Dennett senão esporádicos acenos sempre superficiais ou polêmicos.

A maior parte de Breaking the spell é dedicada a reconstruir os mecanismos mentais e os percursos evolutivos que fizeram surgir, desenvolver e consolidar as crenças e as práticas religiosas. Para esta reconstrução, Dennett utiliza duas teorias. A primeira é uma aplicação à religião da sua noção de "postura intencional", já elaborada no ensaio The intentional stance (1987); a segunda, que inevitavelmente se refere às relações entre evolução biológica e cultural, se baseia na teoria dos "memes" proposta por Richard Dawkins no seu The selfish gene (1976).

É preciso reconhecer que o tema da "intencionalidade" pode revelar um itinerário muito sugestivo e fecundo. A tendência a tratar todos os outros seres animados como "sistemas intencionais" dotados de crenças e de desejos, de conhecimentos e objetivos se propõe como um dispositivo em condições de conectar a consciência individual às outras consciências. $O$ nosso impulso inato a atribuir aos outros intenções e desejos, esta hiperatividade da mente no uso da postura intencional, teria criado as idéias dos fenômenos pré-religiosos: sepultamento ritual dos cadáveres pelos Neandertalenses, animismo, xamanismo, etc., das quais as religiões atuais seriam somente a sua versão domesticada. $\mathrm{Na}$ realidade, porém, a reconstrução da religião pré-histórica oferecida por Dennett, 
se for confrontada com aquelas baseadas em pesquisas arqueológicas, torna-se totalmente especulativa, estéril e banalmente reduzida ao aspecto materialista.

Há dois elementos que o encaminham a um resultado frustrante. $\mathrm{O}$ primeiro é a sua definição de mente como "dispositivo de exploração" e reprodução. Porém, não há dúvida de que a mente também é um extraordinário dispositivo de "invenção" e de "elaboração" cognitiva. Menosprezar estas dimensões em favor daquela mais darwinista e positivista de "exploração" pode tornar muito difícil dar uma justificativa ao surgimento e ao desenvolvimento das linguagens simbólicas como a arte, a música, ou as religiões (mas, também, naturalmente, da matemática). O fato é que Dennett aplica uma idéia de racionalidade utilitarista, sendo obrigado, dessa forma, a introduzir o velho dualismo entre idéias selvagens e idéias domesticadas e a descontinuidade entre as interpretações religiosas do mundo e as científicas.

O segundo elemento é a definição operacional das religiões como "sistemas sociais cujos aderentes professam crer num ou mais agentes sobrenaturais dos quais pedem a aprovação". Observe-se que tal definição tende a considerar a religião como algo de ingênuos facilmente influenciáveis. Centrado na profissão de fé de um fiel, sem considerar as elaborações teológicas presentes em quase todas as religiões, o autor ignora que as crenças na maioria das vezes se radicam em sentimentos e dão origem a emoções muitas vezes mais importantes do que as próprias crenças.

O aspecto mais paradoxal do livro de Dennett, todavia, é o seu recurso, para explicar os mecanismos de replicação e de sucesso das idéias religiosas, à teoria do "meme egoísta". Supostamente, o meme é como um gene - a unidade à luz da qual a evolução faz sentido - só que enquanto o gene tem uma identidade biológica razoavelmente definida, o meme não a tem. $\mathrm{O}$ sentido do meme é captado no ditado popular de que as idéias são como as viroses: espalhamse quase sem intervenção consciente das pessoas envolvidas: uma música popular, um costume social, um mito, uma moda. Um meme é algo que se transmite culturalmente e que sofre mutações nessa transmissão. As regras que regulam a sobrevivência ou o desaparecimento dos genes aplicar-se-iam também aos memes. Assim, qualquer fenômeno cultural poderia ser explicado do mesmo modo que se explica os traços biológicos das espécies.

É ingênuo pensar que só porque um dado gene ou meme sobreviveu, é benéfico para o seu hospedeiro. Muitas vezes, um gene ou meme é pura e simplesmente inócuo para o seu hospedeiro; outras vezes, é positivamente prejudicial. A que categoria pertence então a religião? É benéfica, prejudicial ou neutra? Que contribuição deu o meme da religião para a sobrevivência e a adaptação dos seres humanos? Há dados científicos, ainda não conclusivos, que mostram que a religião é neutra quanto à maldade ou bondade que as pessoas já trazem consigo — nas prisões norte-americanas, por exemplo, a percentagem 
relativa de religiosos e ateus é sensivelmente igual à percentagem nacional.

Para Dennett, a religião é um fenômeno natural cuja função se esgotou. $\mathrm{Na}$ realidade as razões essenciais que ele apresenta para sustentar esta tese (1. o fato de que a religião exige um ato de fé; 2 . o fato de que o fundamentalismo religioso pode ser socialmente perigoso) certamente não são convincentes:

1. Aquela que ele considera a herdeira mais fiável da religião, a ciência, muitas vezes exige, da maior parte dos cidadãos, inevitavelmente ignorantes das investigações que se desenvolvem nos laboratórios, um ato de fé igual ao solicitado pela religião.

2. Nada garante que o fundamentalismo técnico-científico seja menos perigoso do que o religioso.

A perspectiva de Dennett é claramente ateísta. Isto poderia constituir um grande obstáculo à pesquisa, mesmo porque ainda é difusa a convicção de que o estudo da religião deve ser reservado somente aos fiéis. Uma das dificuldades mais árduas é justamente esta: convencer os crentes que o estudo da religião pode ser útil também a eles. Como? Reforçando as próprias crenças no confronto com as demais. Que religião pode aspirar a erigir-se depositária da Verdade se impedir tal verdade de se confrontar com as outras opiniões?

Everaldo Cescon (everaldocescon@hotmail.com)

Pós-doutorando em Filosofia na Universidade de Lisboa. Bolsista da Fundação para a Ciência e Tecnologia - Portugal. Doutor em Teologia, Pontifícia Universidade Gregoriana - Itália. Professor da Universidade de Caxias do Sul - Brasil. 